\title{
Resources for Service Quality Improvement as Competitive Advantages: A Conceptual Model for Services Firms in Vietnam
}

\author{
Hoa Quynh Thi Bui ${ }^{1} \&$ Thanh Hai Nguyen ${ }^{2}$ \\ ${ }^{1}$ Maastricht School of Management (MSM), the Netherlands \\ ${ }^{2}$ Monash University, Australia \\ Correspondence: Hoa Quynh Thi Bui, Maastricht School of Management (MSM), the Netherlands. E-mail: \\ quynhsaga@gmail.com
}

Received: April 9, 2012 Accepted: June 21, 2012 Online Published: August 28, 2012

doi:10.5539/jsd.v5n9p141 URL: http://dx.doi.org/10.5539/jsd.v5n9p141

\begin{abstract}
The main aim of the research paper is to develop a conceptual model for services firms in Vietnam. This model will helps to achieve our research objectives by assessing the resources necessary for service quality improvement as a competitive advantage strategy inside the company, the role of soft factors (human resources factors) for service quality improvement, and critical solutions relating to business operating and management strategy of the company. The arguments are based on the resource based view theory and review of literatures in regional countries. This coming research will be an in-depth qualitative study using content analytic approach.
\end{abstract}

Keywords: resource, service quality, soft factors, competitive advantages

\section{Introduction}

Many scholars argue that firms are competing in a very difficult and challenging business atmosphere that are being transformed by many factors, from globalization, technological development and progressively more rapid diffusion of technology, to the expansion and use of information (Hitt et al., 1998; Cullen, 2002; Alam \& Pacher, 2003). Vietnam is in the process of transforming from a central planned economy to market economy. Obviously, the process of globalization and recent economic recession has also influenced the Vietnamese business environment significantly and made it become more and more difficult for firms to do business. This is not exceptional for companies in services sector.

Not much research has been conducted on this matter, especially in the financial services sectors in Vietnam. Unfortunately, not a single conceptual model relating to resources and service quality improvement has been found in the Vietnamese business context.

Therefore, the objective of this paper is to look at the resources conditions, and the critical role of soft factors for quality improvement strategy. This paper constructs a specific conceptual model for firms in services sector in Vietnam to improve its quality of service as competitive advantages. This research paper hopes to contribute to existing knowledge by identifying resources condition contributing to service quality improvement. The conceptual model can be used for future research at the industrial level or between firms within an industry.

\section{Key Research Questions}

1) What are the difficulties that financial service companies are facing in term of resources for enhancing competitive advantages and service quality?

2) To what extent do staffs perceive the importance of soft factors (human resources) associated with quality improvement?

3) To what extent do managerial level evaluate the importance of soft factors (human resources) associated with quality improvement?

4) What implications does a company need to improve its quality of services and to close the gap between its managers' perceived value of soft factor for service quality, as well as employees' perception? 


\section{Theoretical Foundation for the Study - The Resource-Based View}

Not much research attempted on examining all aspect of resources factors contributing to service quality improvement as competitive advantages in Vietnam. Some previous studies of Vietnamese entrepreneurs in Hochiminh city conducted by Australian and Vietnamese researchers have examined the relationship between competitive advantages and firm performance (Nguyen et al., 2008a, b). In those studies, they did not focus on all of the other factors of the company's resources, but focused more on knowledge sharing (which is part of the company resource and capability). They argued that the firms' knowledge management processes are key contributors to firm competitive advantages (CA) and this CA again can positively influence firms' performances. Their studies also argue that developing organizational knowledge capability and competitive advantage, entrepreneurial culture is of special importance for firms in Vietnam.

Lakhal (2009) develops a framework for accessing the positive contribution of quality improvement process to enhancing competitive advantage and organizational performance. The study indicates the connection between quality, competitive advantage, and organizational performance. More importantly, the company's quality improvement can directly or indirectly enhance the firm's competitive advantage and strengthen the performance.

Empirical evidence from literature review suggests that there are some criticisms of the resource-based view. Priem and Butler (2001) raised some issues of limitations: This theory has limited applications. Various resource arrangements can produce the equivalent value for companies and as a result would not be competitive advantage. The position of product markets is weak in the argument of this theory (Barney, 1991). This theory does not take into account the external factors in relation to the industry as Porter $(1979 ; 1990)$ has proposed. According to some critiques, a recognized resource of sustainable competitive advantages is fundamental uncertainty (Lippman \& Rumelt, 1982).

Porter (1990) suggested a National Diamond paradigm for worldwide competitive advantages. His proposal confirmed a number of key elements of domestic competitive conditions that must all be fostered if a firm's success is to be maintained such as demand conditions, government, related and supporting industries, factors conditions, company strategy, structure and rivalry. Nevertheless, his proposed model did not noticeably address the decisive factors for enhancing firm's competitiveness in domestic market competition and for those who are in service sector to enhance quality improvement. More specifically, in order to overcome those matters, he created the home based diamond as direction for firms to decide appropriate approach and business sector to invest or enter. Porter's diamond paradigm (1990) argues that the home base of an organization plays a significant position in shaping the extent to which it is expected to achieve advantage. Nevertheless, the question to be raised from this: why Porter (1990) is discussed in our review of literature, as it is more suitable for an industrial research and seems irrelevant to a case study of a single firm?

Basing on Porter $(1979,1990)$, it can be interpreted that a firm should not be seen as isolated entity, but need to be viewed as existing in an operating environment that being connected with others institutions, facilitated and supported by many factors (Ritter et al., 2004). This suggests us to look for a theory, which is consistent with this view. On the other hand, what is the theoretical foundation for Porter $(1979,1990)$ to be established? For firms who want to overcome their incapability in enhancing competitive advantages, they need to understand what made the company success in doing business. Therefore, the question to be advanced from this is 'what is a firm's resource?

Many scholars have argued for the resource-based view (Rindova \& Fombrun, 1999; Grant, 1991; Barney, 1991). Firm is a combination of different resources, abilities, and key elements of core competencies that can be exploited to produce a good market position (Rindova \& Fombrun, 1999). Therefore, resource and capability are two critical groups of elements to the firm's success. According to those scholars, two kinds of resources are tangible and intangible. Barney (1991) and Jackson et al. (2003) recommended a numbers of factors could be important to the enhancement of competitive advantages using resource-based view. In his investigation, Barney inspects the connection between a firm's characteristic quality and performance (Barney, 1991). On the other view, Grant (1991) depicts resource as company's assets, knowledge, technology know how, brand names, employees' skill, efficient procedures, copyrights, contacts, machinery and facilities and tools. The author argues that resources and capabilities help establish the basic direction for a firm's strategy. Unfortunately, few researchers have attempted to characterize the concept of competitive advantages as observed by Day (1984), Day and Wensley (1988), and Mooney (2007). By referring to Resource based viewed as a theoretical guidance, due to the scope of this paper, it touches the question of resources needed as a means to enhance the firm's capability. 
More specifically, the research will also address the soft factors (human resources factor inside the resources conditions). Many researchers argue for the importance of human factors in quality improvement such as Reason (1990); Wicken, Gorden, and Liu (1998); Abdullah et al. (2008); Lu and Sohal (1993); Rahman (2004); Rahman and Bullock (2005); and Agus (2001). Rahman (2004) defines soft factor as the behavioral management sides of the "human factors", such as leadership, training, human resource management (HRM), employee involvement and empowerment. According to Abdullah et al. (2008) 'the quality improvement models such as Malcolm Baldridge, European Foundation for Quality Management, and the Deming Prize have also identified soft factors such as leadership, process management, training, communication, teamwork, learning as the key aspects for effective quality improvement. These soft factors are key elements to quality improvement because they may have a positive impact on firm performance'. Their investigation proposed four key elements of Management Commitment, Employee Involvement, Training and Education, Reward and Recognition, which play a critical role for quality improvement process (Abdullah et al., 2008).

It is important to emphasize that this theory of resource-based view can give explanation how firms can recognize proper measures to overcome their internal and external obstacles by seeking better access to knowledge, technology, human resources, financial resources, and better quality of service offered to customers. Those previous studies and theoretical foundations provide a strong point for firms in different sectors to recognize that the application of resource-based theory is of special importance. Resource-based theory with specific strategic objectives could be a key theoretical foundation to construct a conceptual model for successful implementation of firm's improvement strategy to enhance business competitive advantages.

\section{Conceptual Model}

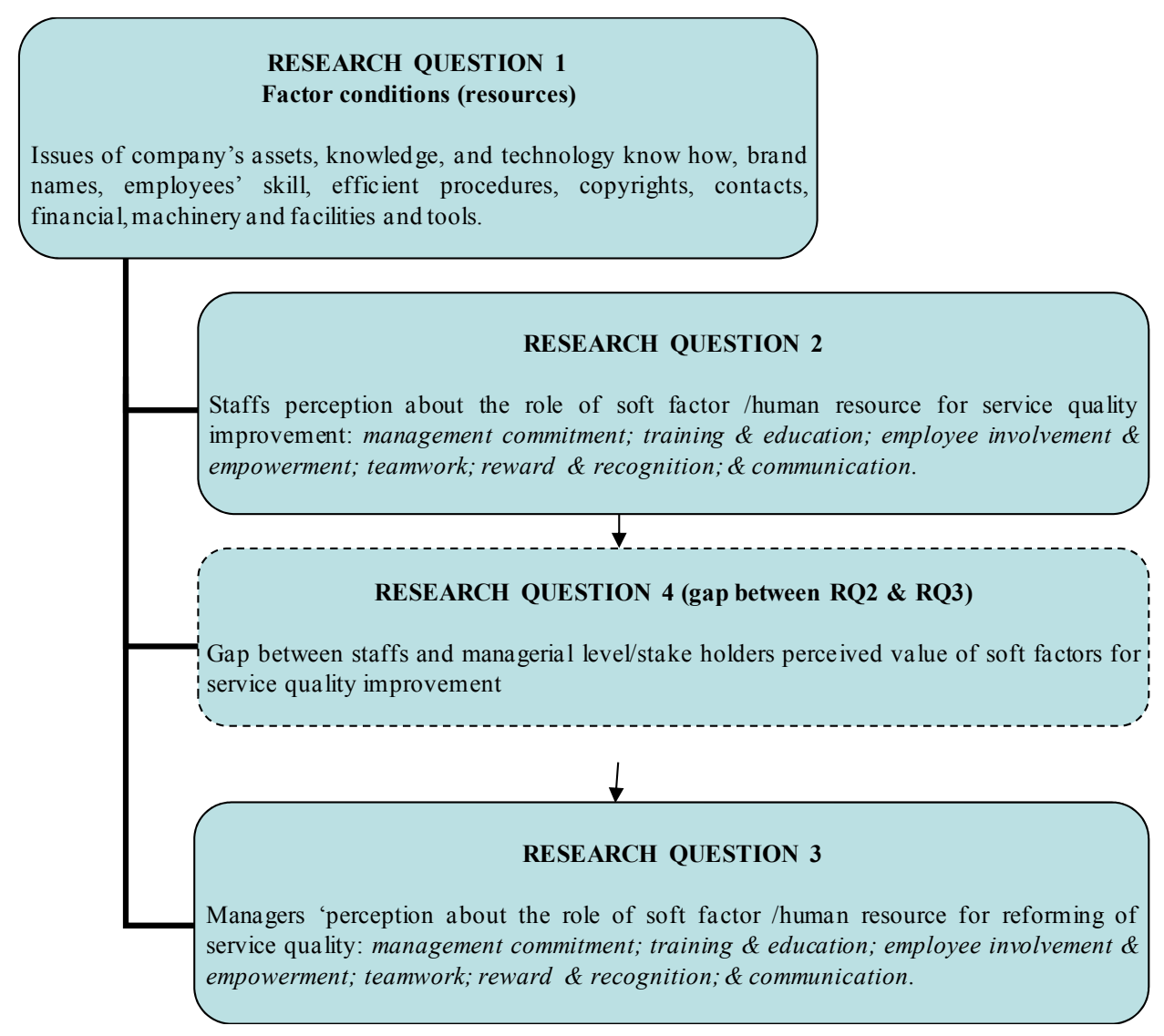

\section{Research Design and Methodology}

\subsection{Research Procedure}

Yin (1984) describes the case study research method as an experimental study that examines a contemporary phenomenon within its real-life context; and when the boundaries between phenomenon and context are not apparent; and in which numerous sources of evidence are used (Yin, 1984). According to Yin (1994), case 
studies can be either single or multiple-case designs, where a multiple design must pursue duplication rather than sampling logic. Yin also argues that, when no other cases are presented for duplication, the researcher is limited to a single case designs and a case study is an in-depth investigation, it is not aiming at generalization. It is made to literature's contribution and not to populations (Yin, 1994).

The research design engages a qualitative technique includes the gathering and examination of primary data and secondary data. Qualitative analysis will be used as exploratory study for gaining deeper insight into the problems. Sample sizes will be depended on the scope of the company (or industry in future research). The research will employ the content analytic approach for data analysis in looking for themes, common pattern. Emerging themes or factors will be considered and analyzed using this analytic approach.

\section{Discussion}

This is a single case study scope, as Yin (1994) pointed out that any generalization of outcomes, from either single case or multiple designs, is made to literature contribution and not to populations. Therefore, it has its own limitation in term of size, application (generalization capability).

To this point, it is important to highlight that when existing literature about this issue are still an on-going debate and not much research topic (applied the concept of Resource based view) has been done in the context of a Vietnamese services sector, an exploratory study to look into the nature of the dilemma is crucial. Despites its key contributions, further investigation of this applied research in quantitative analysis is required to test the conceptual model in larger sample (companies/industries) due to the research's limitation of scope, times, and location.

\section{Acknowledgement}

The authors would like to acknowledge for the significant contribution and invaluable guidance, Dr. Hans Stoessel (Former Director of Swiss-Asian Institute of Technology (SAV) Program in Vietnam) made to the preparation of this research paper.

\section{References}

Abdullah, M. M. B., Ahmad, Z. A., \& Ismail, A. (2008). The Importance of Soft Factors for Quality Improvement: Case Study of Electrical and Electronics Firms in Malaysia. International Journal of Business Management, 3(12), 60-69.

Agus, A. (2001). The structural linkages between TQM, product quality performance, and business performance: Preliminary empirical study in Electronics companies. Singapore Management Review, 27, 87-105.

Alam, Q., \& Pacher, J. (2003). Internationalisation of Australian SMEs: Challenges and Opportunities. In Wright, R., \& Etehmad, H. (Eds.), Globalisation and Entrepreneurship: Policy and Strategy Perspectives, (pp. 85-105), Edward Elgar, U.S.A.

Barney, J. (1991). Firm resources and sustained competitive advantage. Journal of Management, 17(1), 99-120. http://dx.doi.org/10.1177/014920639101700108

Barney, J. B. (1986a). Strategic Factor Markets: Expectations, Luck and Business Strategy. Management Science, 32(10), 1231-1241. http://dx.doi.org/10.1287/mnsc.32.10.1231

Barney, J. B. (1986b). Organizational Culture: Can It be a Source of Sustained Competitive Advantage? Academy of Management Review, 11(3), 656-665.

Barney, J. B. (2001). Is the Resource-Based Theory a Useful Perspective for Strategic Management Research? Yes. Academy of Management Review, 26(1), 41-56.

Barney, J. B., Wright, M., \& Ketchen Jr., D. J. (2001). The resource-based view of the firm: Ten years after 1991. Journal of Management, 27(6), 625-641. http://dx.doi.org/10.1177/014920630102700601

Chaharbaghi, K., \& Lynch, R. (1999). Sustainable competitive advantage: towards a dynamic resource-based strategy. Management Decision, 37(1), 45-50. http://dx.doi.org/10.1108/00251749910252012

Cullen, J. B. (2002). Multinational Management: A strategic approach (2nd ed.). Ohio: South-Western.

Day, G. S. (1984). Strategic market planning: the pursuit of competitive advantage. St. Paul, MN: West.

Day, G. S., \& Wensley, R. (1988). Assessing advantage: A framework for diagnosing competitive superiority. Journal of Marketing, 52, 1-20. http://dx.doi.org/10.2307/1251261 
Hitt, M. A., Keats, B. W., \& DeMarie, S. M. (1998). Navigating in the new competitive landscape: Building strategic flexibility and competitive advantage in the $21^{\text {st }}$ century. Academy of Management Executive, $12(4), 22-42$.

Jackson, S. E., Hitt, M. A., \& DeNisi, A. S. (2003). Managing knowledge for sustained competitive advantage: designing strategies for effective human resource management. San Francisco: Jossey-Bass

Lakhal, L. (2009). Impact of quality on competitive advantage and organizational performance. Journal of the Operational Research Society, 60(5), 637-645. http://dx.doi.org/10.1057/palgrave.jors.2602601

Lippman, S. A., \& Rumelt, D. P. (1982). Uncertain Imitability: An Analysis of Interfirm Differences in Efficiency under Competition. The Bell Journal of Economics, 13(2), 418-438. http://dx.doi.org/10.2307/3003464

Lu, E., \& Sohal, A. (1993). Success factors, weaknesses and myths concerning TQM implementation in Australia. Total Quality Management, 4, 245-255. http://dx.doi.org/10.1080/09544129300000039

Mooney, A. (2007). Core competence, Distinctive Competence, and Competitive Advantage: What is the $\begin{array}{lllll}\text { difference? Journal of Education for } & \text { Business, } & \text { 83(2), } & \text { 110-111. }\end{array}$ http://dx.doi.org/10.3200/JOEB.83.2.110-115

Nguyen, T. N. Q., Neck, A. P., \& Nguyen, T. H. (2008a). The Relationships between Entrepreneurial Culture, Knowledge Management and Competitive Advantage in A Transitional Economy. 17th Biennial Conference of the Asian Studies Association, Asian Studies Association of Australia-ASAA, Melbourne, Australia.

Nguyen, T. N. Q., Neck, A. P., \& Nguyen, T. H. (2008b). Western model versus Eastern culture: developing organizational knowledge capability and competitive advantage -think globally act locally. Australasian Journal of Business and Social Inquiry, 6(3), 42- 61.

Porter, M. E. (1990). New Global Strategies for Competitive advantage. Planning Review, 18(3), 4-14.

Porter, M. E. (1979). How Competitive Forces Shape Strategy. Harvard Business Review, 57(2), 86-93.

Priem, R. L., \& Butler, J. E. (2001). Tautology in the Resource-Based View and Implications of Externally Determined Resource Value: Further Comments. Academy of Management Review, 26(1), 57-66.

Rahman, S. (2004). The future of TQM is past. Can TQM be resurrected? Total Quality Management, 15, 411-422. http://dx.doi.org/10.1080/1478336042000183550

Rahman, S., \& Bullock, P. (2005). Soft TQM, hard TQM, and Organizational Performance Relationships: an Empirical Investigation. Omega, 33, 73-83. http://dx.doi.org/10.1016/j.omega.2004.03.008

Reason, J. (1990). Human error. Cambridge, England: Cambridge University. http://dx.doi.org/10.1017/CBO9781139062367

Rindova, V. P., \& Fombrun, C. J. (1999). Constructing Competitive Advantage: The Role of Firm-Constituent $\begin{array}{lllll}\text { Interactions. } & \text { Strategic }\end{array}$ http://dx.doi.org/10.1002/(SICI)1097-0266(199908)20:8<691::AID-SMJ48>3.0.CO;2-1

Ritter, T., Wilkinson, I. F., \& Johnston, W. J. (2004). Managing in complex business network. Industrial Marketing Management, 33, 175-183. http://dx.doi.org/10.1016/j.indmarman.2003.10.016

Wickens, C. D., Gordon, S. E., \& Liu, Y. (1998). An Introduction to Human Factors Engineering, New York: Addison-Wesley, Educational Publishers, Inc.

Yin, R. K. (1984). Case Study Research: Design and methods. Newbury Park, CA: SAGE.

Yin, R. K. (1994). Case Study Research. SAGE Publications. 